\title{
Developing Worksheet Based on Multiple Intelligences to Optimize the Creative Thinking Students
}

\author{
Anida Luthfiana ${ }^{1 *}$, Alben Ambarita ${ }^{2}$, Suwarjo ${ }^{3}$ \\ ${ }^{1}$ Faculty Education and Training Teacher, University of Lampung, \\ St. Prof Dr. Soemantri Brojonegoro No. 1 Bandar Lampung, Indonesia. \\ *E-mail : anidaluthfi516@gmail.com
}

Article received: 10-04-2018, article revised: 30-08-2018, article published: 07-09-2018

DOI : 10.25273/jipm.v7i1.2430

\begin{abstract}
The research and development of worksheet based on multiple intelligences aims to develop and describe the effectiveness of worksheet based on Multiple Intelligences to optimizing the ability of creative thinking students. The type of research used is research and development that refers to the theory of Borg \& Gall. The population of this research is the students of $5^{\text {th }}$ grade of Primary School in Metro East. The sample of this research was 33 students of $5^{\text {th }}$ grade in Islamic Primary School of Wahdatul Ummah Metro is determined using purposive sampling technique. Data were collected used questionnaires and test questions. The results showed that worksheet based on Multiple Intelligences effectively optimize the creative thinking students.
\end{abstract}

Keywords : Student Worksheet; Multiple Intelligences; Creative Thinking

\section{INTRODUCTION}

$21^{\text {st }}$ century education requires students to process the information they learn through the activities of analysis, assessing, and creating. Students should be able to use the information obtained to create something new, be able to make sensible opinions, communicate the knowledge gained, and work with other students to build a more optimal ability. So the ability that must have students in the $21^{\text {st }}$ century is creativity, critical thinking, communication, and collaboration (Bialik, Fadel, Trilling, Nilsson, \& Groff, 2015). For many years, educators have implemented traditional teaching methods in the classroom that have tended to classify students as a homogeneous group where teachers use the executive approach to transmit knowledge to all the students with a similar set of teaching methods (Sulaiman, Hassan, \& Yi, 2011). Gunst (Dolati \& Tahriri, 2017) who conducted a research on Catholic elementary school stated:

Teachers tend to use teaching strategies that are aligned with their self-reported multiple intelligence. However, teachers need to be able to move beyond their strongest intelligence and incorporate several approaches in classrooms where students have varying abilities, interests, and aptitudes.

Each student is a unique and different individual, so learning in the classroom should be able to facilitate the student's diverse abilities. According to Gardner's theory (Gardner, 2011) multiple intelligences has several implications for teachers in term of classroom instruction. Since all children do not learn in the same way, they cannot be assessed in the same way. Knowing how each student learns will allow the teacher to properly assess the child's progress. (Yalmanci \& Gözüm, 2013) stated, Gardner's Multiple Intelligences theory has two important advantages in education. First, it paves the ways for planning the education program in a way that students realize their potentials and move toward their desires. Second, it makes it possible for us to reach students who are more active because learning 
would be more attractive in a condition that learners are trained through the use of these intelligences. This happens when the teacher's lesson plan includes a variety of activities that are related to various types of intelligences (Tapia Carlín, Castillo Salazar, \& Velázquez Cortés, 2013).

The ability of creative thingking is ability that must have students in the $21^{\text {st }}$ century. Creativity is unique, different, variety, and innovative. So that, learning should be based multiple intelligences. (Gardner, 2011) proposed that each person has different capabilities and tendencies in different areas and that each individual has several types of intelligences that are intermingled in different ways. This research was focus in mathematics subject, because for many studies mathematics only practice logicalmathematical type in learn without used the other intelligences.

Mathematics is used to practice thinking and reasoning skills so as to solve real-life problems. (Burns, 2014) states the goals of mathematics instruction today are cleardevelop children's ability to think and reason mathematically and help them learn the concepts and skills they need to do so, skills in all of the content areas of mathematics to a range of problem-solving situations.

TIMSS or Trend in International Mathematics and Sciences Study is international study center at fourth and eighth grades in special advanced mathematics and physics programs. The questions in the TIMSS for mathematics consisted of four parts that is; the category low (basic mathematical knowledge), intermediate (basic mathematical knowledge in simple situations), high (knowledge and understanding to solve problems), and advanced (understanding and knowledge in a variety of relatively complex situations and explain their reasoning) (Mullis, Martin, Foy, \& Hooper, 2016). The categories of questions in TIMSS are oriented towards the ability to understand, solve problems and reason. Therefore, Categories of TIMSS have been reflected in the aims of mathematics learning so that students have the ability to understand, the ability to use reasoning, problem solving skills, the ability to communicate and have the attitude of appreciating mathematics (Depdiknas, 2006).

The result of the TIMSS study in 2015 for $4^{\text {th }}$ grade students shows that Indonesia ranked 44 out of 56 countries with an average score of 397 . The average score of all countries is 500 so that Indonesia is categorized as country average significantly lower (Mullis et al., 2016). TIMSS' data show that Indonesian students' math skills improved below average score on an international level.

Based on the search of documentation of mathematics learning result in East Metro on 279 students of $5^{\text {th }}$ grade, the average data of students who have not reached minimal mastery criteria in math lesson is $48,49 \%$. This percentage of inadvertence is low because ideally learning is said to be successful if at least $75 \%$ of students are able to achieve minimal mastery criteria. The analysis of the students' needs was conducted with the target of 120 students of $5^{\text {th }}$ grade Primary School in East Metro. Based on the analysis of students' creative thinking ability in learning mathematics, the result shows that the indicator of students' creative thinking ability which get percentage below $50 \%$ is on the experimental indicator and give different examples from the existing example, respectively $28,3 \%$ and $40,8 \%$. The low percentage of indicators performing the experiments is thought to be due to experimental activities in finding a mathematical concept that is less interesting or too complicated. While the indicator provide different examples with existing examples allegedly because students are given less opportunity to analysis mathematical problems, or students accustomed to faced with math problems only on the level of knowledge and understanding. Accordingly, the action of the local education system to implement the higher order thinking skills (HOTS) element proposes to enable rational science subjects in various students in the hopes of expanding the scope of intelligence. The act opened more branches of evaluation in addition to evaluation or assessment only oriented 
towards verbal-linguistic and logical mathematical intelligences.

According to (Gardner, 2011) one's intelligence - suddenly - is not measured from the results of standard psychological tests, but can be seen from one's habit of two things. First, one's habit of solving a problem. Second, a person's habits create new products that have cultural value (creativity). The ability to think creatively is a highlevel thinking ability. Creative thinking skills is higher order thinking skills (Runisah, Herman, \& Dahlan, 2016). According to (Susanto, 2014) creative thinking can be interpreted by thinking that can connect or see things from a new point of view. According to (Judge et al., 2014) there are four aspects of the ability to think creatively is fluency, flexibility, originality and elaboration. The four aspects according to Guilford are used as indicators in this study to measure the creative thinking ability of students.

(Susanto, 2014) describes the indicator on creative thinking skills are (1) Fluency; answer with a number of answers, fluently in exposing ideas, can see the error or lack of a situation, object, or statement. (2) Flexibility; capable of providing different ways to solve problems, giving various interpretations of images, stories, or problems. (3) Originality; give different answers to others, choose the asymmetry in the drawing or create the design, after reading or hearing the idea of working to find a new solution. (4) Elaboration; seeking deeper meaning for answers by taking detailed steps, developing other people's ideas, drawing lines, colors and details about the pictures themselves or others.

The efforts to facilitate students to get used to solve problems and to develop their creativity are through a structured and varied activities. These activities can be arranged in such a way in a teaching materials in the form of Student Worksheet. According to (Prastowo, 2015) Student Worksheet is a printed material in the form of sheets of paper containing materials, summaries, and instructions on the implementation of learning tasks to be done students, which refers to the basic competencies that must be achieved. Student Worksheet can be useful in many ways including academic achievement. For example, as a supplement to books, providing additional information for a particular class, can help students construct knowledge, otherwise Student Worksheet will be able to attract students when combined with specific teaching methods (Lee, 2014).

The preparation of Student Worksheet is done with the aim to provide instructional materials that suit the curriculum requirement according to the needs and the characteristics and environment of the students, increase the learning resource for the students, and facilitate the teacher in carrying out the learning. Based on these objectives, the preparation of Student Worksheet should consider the needs and potential of different students. This potential is then referred to as intelligences.

Based on research conducted (Gardner, 2011) gives result that each individual has more than one intelligence, called multiple intelligences. According to (Jasmine, 2016) multiple intelligence is the existence of multiple intelligences or more than one intelligence on someone. (Gardner, 2011) specifies that multiple intelligences of each individual consist of linguistic intelligence, music intelligence, logical-mathematical intelligence, spatial intelligence, bodily - kinesthetic intelligence, and the personal intelligences.

(Derakhshan \& Faribi, 2015) mention that multiple intelligence strategy should be applied in classes in order to boost up the students' learning skills. (Yalmanci \& Gözüm, 2013) explains that when using multiple intelligences strategies in learning then students will be more successful in academics. Worksheet base on Multiple intelligences that can support students in learn by doing so that can make learning more pleasant. Worksheet can be useful for develop varied activities in many ways with support multiple intelligences that considered several different of intelligences. Different capabilities each 


\section{JIPM (Jurnal Ilmiah Pendidikan Matematika), 7(1), September 2018 - 4}

Anida Luthfiana, Alben Ambarita, Suwarjo

student can be facilitate with worksheet base on multiple intelligences, so that student can be exist the creativity in learn.

Therefore, the alternative used to develop and improve the ability of creative thinking is with the development of Mathematics Students Worksheet based multiple intelligences. The purposes of this research and development are (1) Produce Students Worksheet mathematics product based on multiple intelligences in $5^{\text {th }}$ grade of Primary School to optimize the creative thinking students. (2) Describe the effectiveness of Student Worksheet based on multiple intelligences on the creative thinking ability of students in learning mathematics in $5^{\text {th }}$ grade of Primary School.

\section{METHODS}

The type of research used is Research and Development (R \& D) model of Borg \& Gall (1989, p. 781). Research and Development (R \& D) model of Borg \& Gall has steps consisting of (1) Research and Information Collecting, (2) Planning, (3) Develop Preliminary Form of Product, (4) Preliminary Field Testing, (5) Main Product Revision, (6) Main Product Revision, (7) Operational Product Revision, (8) conducting final product trials, (9) revising the final product, and (10) disseminating and implementing the product. From those ten steps the researchers set to implement until the seventh step.

The study population was 279 students. Sampling technique used is purposive sampling technique and obtained sample amounted to 33 students in $5^{\text {th }}$ grade of Islamic Primary School of Wahdatul Ummah Metro. Instruments used for data collection are a questionnaire for collected the student needs, obeservation sheet of material expert, media expert, and practitioner, and questions test for collected the study result. Creative thinking students is measure with study result which is the questions test arrange based indicator of creative thinking ability. The feasibility analysis of Student Worksheet is obtained from the product validation result calculated using the formula:
Final Score $=\frac{\text { obtained score }}{\text { Maximum Score }} \times 100$

The final score is converted to the following assessment criteria can be viewed on table 1 below.

Table 1. Criteria Product Validation Result

\begin{tabular}{lc}
\hline Criteria & Value \\
\hline Very Good & $76-100$ \\
Good & $51-75$ \\
Less & $26-50$ \\
Very Less & $\leq 25$ \\
\hline
\end{tabular}

Tests of creative thinking skills of students are prepared based the indicators of creative thinking. This test is done by students twice as much as on pre-test and post-test. The test results of the ability of students to be one reference in determining product effectiveness of Student Worksheetbased Multiple Intelligences on learning mathematics of $5^{\text {th }}$ grade Primary School. The indicator of students' creative thinking ability test is as follows.

Table 2. Indicator of Students' Creative Thinking Ability Test

\begin{tabular}{ll}
\hline $\begin{array}{l}\text { Aspect of } \\
\text { Creative } \\
\text { Thinking Skill }\end{array}$ & $\begin{array}{l}\text { Indicator of Creative Thinking } \\
\text { Ability }\end{array}$ \\
\hline Fluency & - Answering the questions \\
& coherently and thoroughly. \\
& - Answer more than one answer. \\
Flexibility & - Answering questions varied. \\
& - Provide alternative ways of \\
& completion \\
Originality & - Gives an answer other than the \\
& usual. \\
& - Give different answers to other \\
& friends. \\
& - Develop or enrich the idea of \\
& an answer to a question. \\
Elaboration & Add or detail detailed answers. \\
\hline
\end{tabular}

The effectiveness of the use of Students Worksheet is determined by using the NGain formula as follows.

$$
\mathrm{N} \text {-Gain }=\frac{\text { post }- \text { test score }- \text { pre-test score }}{\text { maximum score-pre-test score }}
$$


Interpretation of $\mathrm{N}$-Gain calculations using the Hake classification $(1999$, p. 84) as follows.

Table 3. Interpretation of N-Gain calculations

\begin{tabular}{lc}
\hline Index Gain & Criteria \\
\hline $\mathrm{g}>0,7$ & High \\
$0,3<\mathrm{g} \leq 0,7$ & Middle \\
$\mathrm{g} \leq 0,3$ & Low \\
\hline
\end{tabular}

Study result determined by using the pairedsample t-tets by SPSS 20 program. The ttest criteria are: 1) If the significance value $\leq \mathrm{H}_{0}$ is rejected and $\mathrm{H}_{1}$ is accepted. 2) If the value of significance> 0.05 then $\mathrm{H}_{0}$ is accepted and $\mathrm{H}_{1}$ is rejected.

\section{RESULT AND DISCUSSION}

\section{Research result}

The results of research and development are described as follows.

\section{Initial Information Collection}

Early information gathering was conducted through preliminary research by analysis student needs, identifying mathematics learning process and collecting learning result documents in $5^{\text {th }}$ grade Primary School. Preliminary research results are used as consideration of Student Worksheet development. This step needs to be done because this research and development is piloting a teaching material in the form of Student Worksheet based Multiple Intelligences which its development should be based on empirical data about the profile and the subject studied.

The results of preliminary research indicate that (1) the learning pattern tends to be conventional and the more learning apply the teacher centered approach. (2) mathematics learning result at Islamic Primary School of Wahdatul Ummah Metro, National Primary School of 4 East Metro, and National Primary School of 5 East Metro, in academic year 2016/2017 shows that $48,49 \%$ of 279 students have not finished yet of minimal mastery criteria in math lesson. (3) students or teachers in asking questions have not shown analytical questions such as why and how. (4) students are given less opportunity to analysis math problems and are accustomed to being faced with problems at the level of knowledge and understanding. (5) as many as $78 \%$ of the 9 teachers have not developed their own student worksheet.

Based on the needs analysis, it is necessary to develop Student Worksheet to overcome the existing problems so as to actively involve students in building concepts and make learning more interesting and fun and meaningful. The developed Student Worksheet is Student Worksheet based Multiple Intelligences that is able to optimize the creative thinking ability of students.

\section{Planning}

Development planning of student worksheet based on Multiple Intelligences is done by steps (1) curriculum analysis, and (2) designing of student worksheet development based on multiple intelligences.

\section{Development of Student Worksheet}

Student worksheet is developed in accordance to the student worksheet framework that has been compiled. The preparation of the student worksheet draft consists of: (a) cover, (b) introduction, (c) Mapping of core competencies, basic competencies, indicators, and learning objectives, (d) instructions on using student worksheet, (e) material (f) bibliography. Draft of students worksheet based on multiple intelligences as follows: 


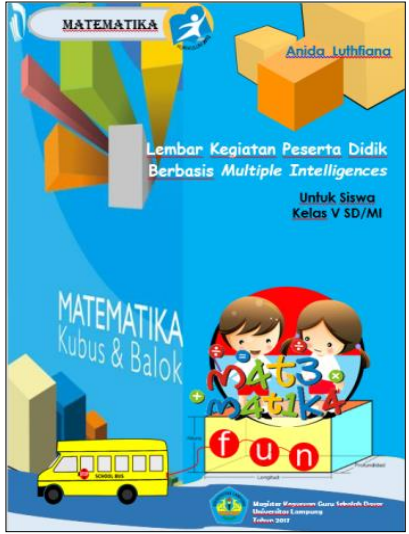

Figure 1. Cover

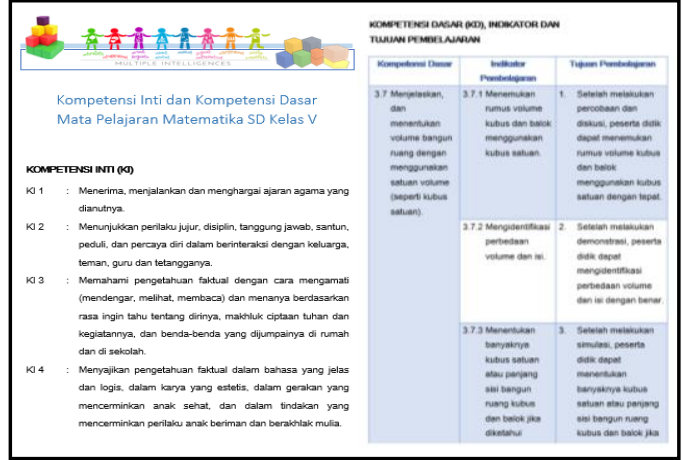

Figure 2. Mapping of core competencies, basic competencies, indicators, and learning objectives
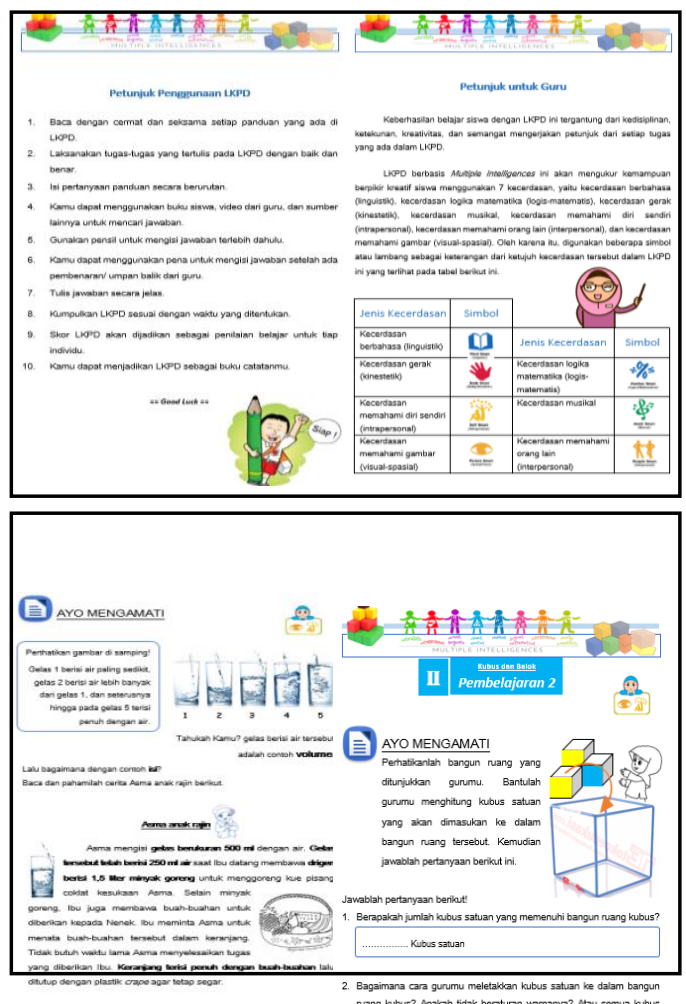

Figure 3. Instructions on using student worksheet
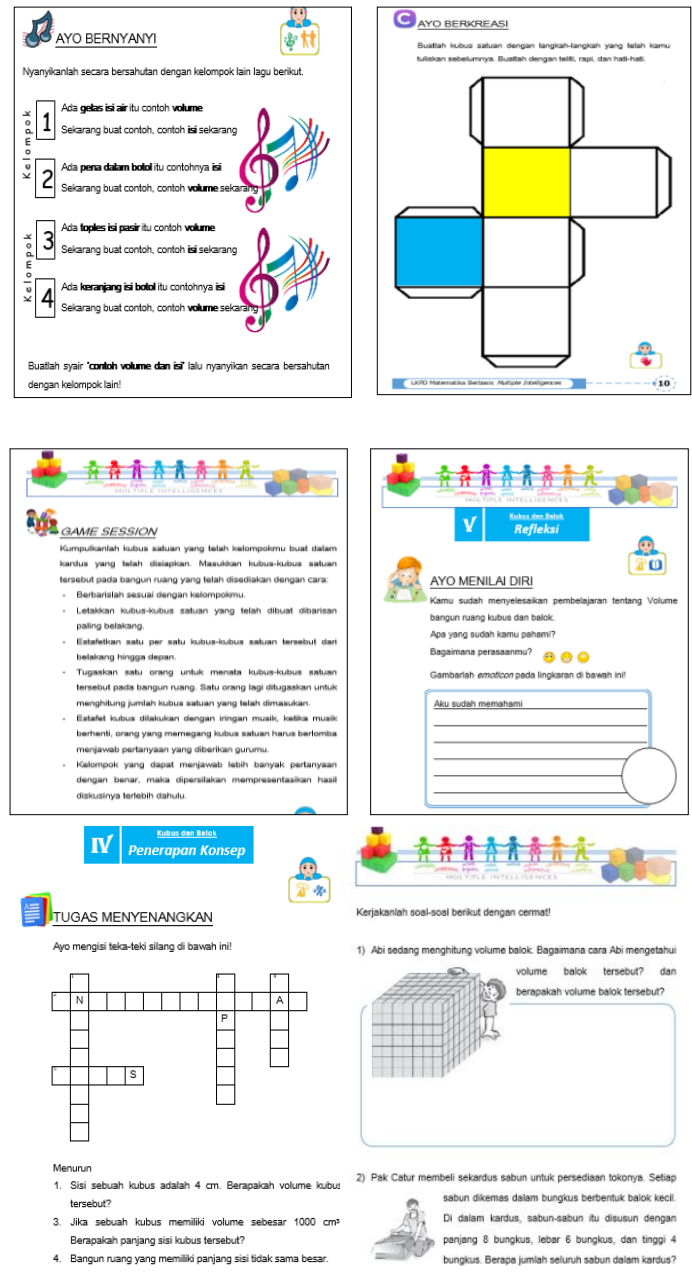

Figure 4. Material

\section{Initial Product Trial}

Initial product testing is done by validating student worksheet on material and design aspects. Student Worksheet validation is done by lecturers of material experts, professors of design experts, and teachers as practitioners.

The student worksheet material expert test aims to gain input on the appropriateness and correctness of instructional materials based on scholarship on the developed student worksheet. The result of material validation by the material experts based on the aspect assessed obtained the value of 82,85 (very good criteria). Based on the expert assessment of the material obtained some suggestions that are (1) indicator related to differences in volume and capacity need to be corrected, and indicators related process indicators that need to be added to the indicator results 
to be measured using instrument questions. (2) The purpose of using student worksheet is better to use operational sentences. (3) The writing section of the cube and beam volume formulas in Lesson 3 is improved.

Expert test design aims to get advice about the accuracy of student worksheet design. The result of design validation by the designer based on the assessed aspect earned 87,50 (very good criteria). Based on the assessment of design experts obtained some suggestions, namely (1) cover page improved to be more interesting for students.

(2) adding the mapping of Core Competencies.

(3) Include a moral message.

Initial product test is also done to practitioner that is Teachers of $5^{\text {th }}$ grade. The validation result by practitioner get the value 88,89 (very good criteria). Based on the assessment by practitioners, the following suggestions were obtained (1) adding concept maps, and (2) adding examples of problems and solutions.

After initial trials by material experts, the media, as well as practitioners. Furthermore, a limited trial was conducted on 10 students in a small group of 3 with low initial ability, 4 with moderate ability, and 3 with high initial ability. The results of small group trials are intended to see the value of pre-test done before the learning and post-test value obtained after following the learning using student worksheet based Multiple Intelligences.

Based on the data recapitulation of small group learning result, it is known that there is an increase of pre-test result with post-test result before and after using student worksheet-based Multiple Intelligences. The average $\mathrm{N}$-Gain in the small group trial was 0,33 (medium category). The average score on the pre-test of 72,851 increased to 80,856 on the post-test.

\section{Initial Product Revision}

Based on student worksheet-based preliminary results of the initial Multiple Intelligences, the next step is to revise the product by taking into account the suggestions of material experts, design experts, teachers, and learning outcomes in small groups. There is an increasing in learning outcomes before learning with after-learning using student worksheet based Multiple Intelligences on a limited trial in small groups. This shows that the creative thinking ability of students is also increasing. After the revision and based on the results of trials in small groups, it is stated that student worksheet-Multiple Intelligences based worthy to be tested in large groups.

\section{Field Trial}

Field product trials were conducted in $5^{\text {th }}$ grade Asma' Binti Abu Bakar, Islamic Primary School of Wahdatul Ummah Metro. The subjects were 33 students. Before implementing the first lesson, students performed the pretest. After studying using student worksheet based Multiple Intelligences, students did post-test. It is intended to determine the effectiveness of student worksheet based Multiple Intelligences by looking at whether or not improvement of learning outcomes before and after implemented learning using student worksheet based Multiple Intelligences.

Based on the recapitulation of learning data of large group students, it is known that there is an increase of pre-test and posttest result with average $\mathrm{N}$-Gain of 0,34 (medium category). The average score on pre-test is 67,477 and it increases in posttest to 82,296 .

\section{Final Product Revision}

The final product revision is based on field trial results and findings when the product is tested. The results of field trials that have been done obtained the learning outcomes of students who increased. Based on the results of the consultation to the material experts and media experts, it is concluded that student worksheet based Multiple Intelligences is not revised and feasible to be implemented.

\section{The effectiveness of Student Worksheet based Multiple Intelligences}

The effectiveness of Student Worksheet can be seen from the improvement of students 'creative thinking ability which is reflected 
from the students' learning result before using Student Worksheet based on Multiple Intelligences and after using Student Worksheet based on Multiple Intelligences. Analysis to compare learning outcomes before and after learning using paired t-test. Before analysis using t-test, test of requirement of analysis is test of data normality using KolmogorovSmirnov T-tested by SPSS 20 program, with test criteria: 1) if significance value > 0,05 then data is normal distribution. 2) If the significance value $<0,05$ then the data is not normally distributed.

Normality test results are known significance value of $0,823>0,05$ then it can be concluded that the data is normally distributed. After the data were tested for normality, the effectiveness test was performed using paired t-test. Based on the calculation is $t_{\text {value }}=-9,510$ with significance value $0,000<0,05$, so $\mathrm{H}_{0}$ is rejected and $\mathrm{H}_{1}$ accepted. This shows a significant improvement in students' creative thinking ability reflected in higher learning achievement after using Student Worksheet based Multiple Intelligences. Based on these calculations, the accepted hypothesis is "Student Worksheet based on Multiple Intelligences effective to optimize students' creative thinking ability".

\section{Discussion}

\section{Development of Student Worksheet based Multiple Intelligences}

This research is a development research that begins by conducting an analysis of the observation result in Primary Schools of East Metro on preliminary research. Early information is obtained that the learning pattern tends to be teacher centered approaches, the result of learning of low student mathematics, and the ability of creative thinking is not optimal, the students do not like the experimental activity, or have not been able to see the mistake of the answer to the problem, and feel confused if given different question kind from the example. Research and mining were conducted on $5^{\text {th }}$ grade Primary School students in East
Metro, with research sample at $5^{\text {th }}$ grade Islamic Primary School of Wahdatul Ummah Metro.

The application of student worksheet based on Multiple Intelligences begins by making lesson plan and compiling student worksheet draft. Learning with student worksheet based on Multiple Intelligences begins with a stimulus through video watching, singing, and playing games about cubes and beams to remind the material characteristics of cubes and beams. Furthermore, learning uses the principle of contextual approach that is factual and convey with real life close to the students, for example with the activity of Rubik to find how to calculate the number of unit cubes in Rubik which can then be used to find the cube and beam volume formula. Active Learning is an integrated activity during learning by involving students and giving students opportunities to always learn by doing. Learning activities end with assessment of learning outcomes to determine the effectiveness of the use student worksheet based on Multiple Intelligences.

Student Worksheet products based on Multiple Intelligences developed have fulfilled the concept of learning and learning. Based on the theoretical constructivism learning theory, learning is the result of constructing students as a result of interaction with the environment. This is consistent with (Susanto, 2014) views that learning according to constructivism theory is that students should find their own and transform complex information, check new information with old rules, and revise it if they are no longer valid. Therefore, the development of student worksheet based on Multiple Intelligences is designed so that students can observe, experience themselves, and obtain the available information in student worksheet in the form of text, pictures, illustrations, or activity steps, thus encouraging students to construct knowledge with their own experience.

The above results are consistent with (Lee, 2014) opinion which states that the 
worksheet can be useful in many ways including academic achievement, for example as a supplement to the book, and adding information. Student Worksheet helps students to understand the material and improve their skills. The design of syntax, design, and materials in student worksheet as well as materials on the implementation of learning using Multiple Intelligences theory. There are seven types of intelligence applied in student worksheet based on Multiple Intelligences according to (Gardner, 2011) those are language intelligence, musical, kinesthetic, visual-spatial, interpersonal, intrapersonal, and logical-mathematical.

Student Worksheet based Multiple Intelligences is developed by applying 7 types of intelligence, namely: 1) language intelligence is developed by observing activities and analysis texts on volume and content, making and reading poems about cube and beam volume, and analysis stories. 2) Musical intelligence is developed by singing and making lyrics about volume and content, and singing the volume of cubes and beams. 3) Kinesthetic intelligence is developed by making the beam nets, and doing the game finds the volume of cubes and beams. 4) Visual-spatial intelligence is developed by drawing cube and beam sketches, watching video activities, observing demonstrations finding cube and beam volumes, and working on labyrinth-shaped questions and images. 5) Interpersonal intelligence is developed by group interaction in singing and making lyrics of volume and content, and gaming involves finding the volume of cubes and beams. 6) Intrapersonal intelligence is developed with individual activities such as doing questions, making and reading poetry, and doing selfreflection. 7) Logical-mathematical intelligence is developed by counting activities, finding the cube and beam volume formulas, and solving the problem of cube and beam volumes.

Based on the implementation of Student Worksheet based on Multiple Intelligences that developed, the activity developed well done. Activities in developing language intelligence are well executed, students are able to analysis the concept of volume and content based on reading texts, interested and enthusiastic students in bolting and reading poetry about the volume of cubes and beams because for them the theme of poetry is unique and other than usual. Activity in developing logical-mathematical intelligence is designed so that students are able to find their own formula and be able to analysis problems in everyday life and make the solution in detail. Intrapersonal intelligence can develop well through a structured step in every activity that can guide students in gaining experience and understanding on the material of the cube and beam volumes. Activities in developing kinesthetic intelligence are done by students with passion, students can build knowledge through experience directly.

Some activities in the Student Worksheet that have deficiencies in developing Multiple Intelligences that is in the development of musical intelligence has not shown the activity of analysis the pattern of rhythm, the activities in the Student Worksheet facilitate the lyrics of songs related to the concept of the volume of cubes and beams. Interpersonal intelligence is designed so that students can work together, but in the implementation not all students participate actively in activities to make a song or play a song. Visual-spatial intelligence is developed as a complement in providing an understanding of the concept of cube and beam volume. The concept of spatial should be maximally given less facilitated due to limited media constraints, for example on the cube framework only shown two in class, it is better if the students are able to obtain their respective framework.

Student Worksheet based Multiple Intelligences are designed to facilitate students according to their potential, with interesting and fun learning. (Susanto, 2014) explains the benefits of learning strategies using multiple intelligences, among others, can generate 


\section{JIPM (Jurnal Ilmiah Pendidikan Matematika), 7(1), September 2018 - 10}

Anida Luthfiana, Alben Ambarita, Suwarjo

learning spirit with drawing activities, creating songs, listening to music, viewing shows such as simulation, game play, which is a sharp entry point to the learning process. In addition, multiple intelligences provide opportunities for students to learn according to their needs, interests, and talents. And students get a positive learning experience and improve the ability to find solutions in troubleshooting issues. (Samsudin, Haniza, Abdul-Talib, \& Mhd Ibrahim, 2015) have research and the result showed a relationship between kinesthetic, logicalmathematical, visual-spatial and naturalistic intelligences with the preferred science teaching. In addition there was a correlation between kinesthetic and visual-spatial intelligences with science process skills, implying that multiple intelligences are related to science learning.

\section{The effectiveness of Student Worksheet based Multiple Intelligences}

The effectiveness of Student Worksheet based on Multiple Intelligences is seen from the learning result obtained by students before and after using Student Worksheet based on Multiple Intelligences. In addition to seeing the effectiveness, the increase in learning outcomes also indicates an increase in the ability of students' creative thinking is optimal. Based on the effectiveness test using $\mathrm{n}$-gain obtained the average of $\mathrm{n}$-gain learning result is 0,34 (medium category). Analysis of the effectiveness of Student Worksheet based on Multiple Intelligences is also done by performing t-test which shows that the significance value is $0,000<$ 0,005 so it is proven that Student Worksheet based on Multiple Intelligences is effective to optimize creative thinking ability of students in $5^{\text {th }}$ grade Asma' Binti Abu Bakar in Islamic Primary School of Wahdatul Ummah Metro.

The effectiveness test is performed with a learning outcome test designed and assessed based on four indicators of creative thinking ability ie smooth thinking, flexible thinking, original thinking, and detailed capability. Based on the test results learned that the ability to think smoothly students seen when students can answer the problem with coherent and thorough although there are some that are not true in answering. But no one meets the indicators answer more than one answer. In the ability to think flexibly students are able to answer questions with diverse and provide different answers alternative. This indicates that the student is confident with the written answer. In students' original thinking skills give different answers to the examples given during the lesson, although some students have similar answers but none at all. In detailing the ability of students to write in accordance with the steps that must be done and able to develop answers through various explanations.

The results of this study indicate that the use of student worksheet-based Multiple Intelligences can optimize the creative thinking ability of students. This is supported by research conducted by (Yaghoob \& Hossein, 2016) on 270 research subjects at Senior High School. The research is published in the journal Educational Research and Reviews that showed "there is relationship between the multiple intelligences and the academic performance achievement levels of high school students". This is also in accordance to the theory written by (Gardner, 2011) that learning with multiple intelligences can optimize the ability of students. Further explained that intelligence can be seen from the ability of a person to solve the problem, and the ability of a person to create new products that have cultural value (creativity).

The results of research on the development of student worksheet-based Multiple Intelligences in accordance to the opinion of (Töman, Akdinez, Obdaşi Çimer, \& Gürbüz, 2013) that student worksheet developed with constructivism approach allows students to participate actively during learningactively participate during the learning process, to learn the subject better, and increase student success noticeably. Accordance to (Anwar, 2012) that creative thinking is a way of generating ideas that can in some way be applied to the world. This often involves problem solving utilizing 
particular aspects of intelligence, for example linguistic, mathematical and interpersonal.

\section{CONCLUSION}

The products produced in this research and development are Student Worksheet-based Multiple Intelligences on $5^{\text {th }}$ grade Primary School subjects through material experts

\section{REFERENCES}

Anwar, M. N. (2012). An Examination of the Relationship between Creative Thinking and Academic Achievements of Secondary School Students. International Interdisciplinary Journal of Education, 1(3), 44-53.

Bialik, M., Fadel, C., Trilling, B., Nilsson, P., \& Groff, J. (2015). Skills for the 21st Century: What Should Students Learn? Retrieved from http://curriculum redesign.org/wp-content/uploads/ CCR-Skills_FINAL_June2015.pdf

Burns, M. (2014). About Teaching Mathematics. USA: Math Solution Publitions.

Depdiknas. Lampiran 1 Permendiknas No. 22 Tahun 2006 tentang Standar Isi (2006). Indonesia.

Derakhshan, A., \& Faribi, M. (2015). Multiple Intelligences: Language Learning and Teaching. International Journal of English Linguistics, 5(4), 63-72. https://doi.org/10.5539/ijel.v5n4p63

Dolati, Z., \& Tahriri, A. (2017). EFL Teachers' Multiple Intelligences and Their Classroom Practice. SAGE Open, 7(3), 1-12. https://doi.org/ $10.1177 / 2158244017722582$

Gardner, H. (2011). Frames of Mind; The Theory of Multiple Intelligence. New York: Perseus Book Group.

Jasmine, J. (2016). Profesional's Guide: Teaching with Multiple Intelligences, translate by Purwanto. Bandung: Nuansa.

Judge, J. M., Stukenborg, G. J., Johnston, W. F., Guilford, W. H., Slingluff, C. L., \& Hallowell, P. T. (2014). Design, Development, and Evaluation of a validation, media design experts, and teachers as users. Student Worksheet products based on Multiple Intelligences effectively improve creative thinking students. While the creative thinking ability of students is more developed in the aspect of ability to think flexible with the indicators able to provide an alternative answer.

Novel Retraction Device for Gallbladder Extraction During Laparoscopic Cholecystectomy. Journal of Gastrointestinal Surgery, 18(2), 334-339. https://doi.org/ 10.1007/s11605-013-2292-4

Lee, C. (2014). Worksheet Usage , Reading Achievement, Classes' Lack of Readiness, and Science Achievement: A Cross-Country Comparison To cite this article: Worksheet Usage, Reading Achievement, Classes ' Lack of Readiness, and Science Achievement: A Cross-Count. International Journal of Education in Mathematics, Science and Technology, 2(2), 96-106.

Mullis, I. V. S., Martin, M. O., Foy, P., \& Hooper, M. (2016). TIMSS 2015 International Results in Mathematics. TIMSS \& PIRLS International Study Center at Boston College.

Prastowo, A. (2015). Panduan Kreatif Membuat Bahan Ajar Inovatif. Yogyakarta: Diva Press.

Runisah, Herman, T., \& Dahlan, J. A. (2016). The Enhancement of Students' Creative Thinking Skills in Mathematics through The 5E Learning Cycle with Metacognitive Technique. International Journal of Education and Research, 4(7), 347-360.

Samsudin, M. A., Haniza, N. H., AbdulTalib, C., \& Mhd Ibrahim, H. M. (2015). The Relationship between Multiple Intelligences with Preferred Science Teaching and Science Process Skills. Journal of Education and Learning (EduLearn), 9(1), 53. https:// 
doi.org/10.11591/edulearn.v9i1.1118

Sulaiman, T., Hassan, A., \& Yi, H. Y.

(2011). An Analysis of Teaching

Styles in Primary and Secondary

School Teachers based on the Theory of Multiple Intelligences. Journal of Social Sciences, 7(3), 428-435.

Susanto, A. (2014). Teori Belajar \& Pembelajaran di Sekolah Dasar. Jakarta: Kencana Prenadamedia Group.

Tapia Carlín, R. E., Castillo Salazar, M. del C., \& Velázquez Cortés, S. (2013). A Mexican Study of Multiple Intelligences for Pre-Service Teachers of English as a Foreign Language Un estudio de inteligencias múltiples con futuros docentes de inglés como lengua extranjera mexicanos. $\mathrm{HOW}, \mathrm{A}$ Colombian Journal for Teachers of English, 20, 170-189.

Töman, U., Akdinez, A. R., Obdaşi Çimer, S., \& Gürbüz, F. (2013). Extended Worksheet Developed According to 5E Model Based On Constructivist
Learning Approach. S October 2013

Volume: 4 Issue: 4 Article: 16 ISSN 1309-6249 EXTENDED, 4(4), 173183.

Yaghoob, R. A., \& Hossein, Z. P. (2016). The correlation of multiple intelligences for the achievements of secondary students. Educational Research and Reviews, 11(4), 141-145. https://doi. org/10.5897/ERR2015.2532

YALMANCI, S. G., \& GÖZÜM, A. I. C. (2013). the Effects of Multiple Intelligence Theory Based Teaching on Students' Achievement and Retention of Knowledge (Example of the Enzymes Subject). International Journal on New Trends in Education \& Their Implications (IJONTE), 4(3), 27-36. Retrieved from http://search.ebscohost. com/login. asp $x$ ?direct $=$ true $\& d b=e u e \&$ $\mathrm{AN}=90520293 \&$ site $=$ ehost-live 